\title{
The slag original from the process of sewage sludge incineration selected properties characteristic
}

\author{
Anna Głowacka ${ }^{1, *}$, Teresa Rucińska $^{2}$, and Justyna Kiper $^{1}$ \\ ${ }^{1}$ EDP Department of Sanitary Engineering West Pomeranian University of Technology in Szczecin, \\ al. Piastów 50, 70-311 Szczecin, Poland \\ ${ }^{2}$ EDP Department of Building Physics and Building Materials West Pomeranian University of \\ Technology in Szczecin, al. Piastów 50, 70-311 Szczecin, Poland
}

\begin{abstract}
This work characterizes the physical and chemical properties of slag from combustion of municipal sewage sludge in "Pomorzany" waste treatment plant in Szczecin. The technology of sludge management is based on drying the sludge in low-temperature belt driers, to a content level of at least $90 \%$, dry mass., and then burning in a grate boiler with mobile grate. The research of the slag resulting from combustion of municipal sewage sludge was conducted using reference methods, presenting images from a scanning electron microscope. The tested waste contained from 16.300 to $23.150 \% \mathrm{P}_{2} \mathrm{O}_{5}$ completely soluble in strong acids, $\mathrm{pH} 8.03$, mineral substance $98.73 \%$ dry mass. The content of heavy metals did not exceed the permissible amount specified in the Regulation of the Minister of Agriculture and Rural Development of 18 June 2008 on the implementation of certain provisions of the Act on fertilizers and fertilization (Journal of Laws of 2008 No. 119, item. 765). The screening trials showed that $48.4 \%$ are fractions of $630 \mu \mathrm{m}-1.25$ $\mathrm{mm}$. The results show that the waste code 190112 may be used as: alternative source of phosphorus for direct application to soil treatment, for production of organic - mineral fertilizers and as construction aggregate for production of concrete mortars.
\end{abstract}

\section{Introduction}

In highly industrialized countries, management and disposal of sewage sludge is a logistical, economic and above all an environmental problem. Sewage sludge is characterized by a high organic load, chemical pollutions. It also constitutes a health risk, due to the presence of pathogenic bacteria, viruses and other pathogenic organisms [1-4]. The increase in the degree of sewage treatment increases the amount of sludge. Therefore, an appropriate manner of its disposal must be ensured, allowing for safe use that does not endanger people and the environment. Management and disposal of sewage sludge is achieved through a variety of processes, such as composting, drying, incineration,

\footnotetext{
*Corresponding author: anna.izewska@,zut.edu.pl
} 
pyrolysis and methane fermentation $[1,2,5,6]$. The main areas of sewage sludge utilization are agriculture and land reclamation. Its disposal is most commonly performed by composting, incineration and storage.

In 2013 in Poland, 540.3 thousand Mg of dry mass of municipal sewage sludge was produced [7] of which approximately $41 \%$ was disposed of by storage and accumulation in treatment plants (in landfills, lagoons and sedimentation ponds). Further development trends were, among others, usage in agriculture (20\%) and thermal conversion (14\%). The basic technological processes of disposal of sewage sludge currently used in Polish waste treatment plants include: composting, drying, incineration, pyrolysis and methane fermentation $[1,8,9]$.

In accordance with Annex 4 to the Regulation of the Minister of Economy of 16 July 2015 on admission of waste for storage in landfills, non-stabilized sludge cannot be stored as of 1 st January 2016.

Therefore, one of the best methods of disposal of sewage sludge is the utilization of thermal methods $[2,5,10,11]$. Products resulting from the combustion of sewage sludge are not neutral to the environment. The quantity and quality of pollutants depend on the chemical composition of the deposits, the combustion technology and the exhaust gas treatment. In many countries, incineration of sewage sludge is common. Systems designed for this purpose are equipped with systems for control and removal of pollutants in exhaust gases [12].

The aim of the study was to characterize the physical and chemical properties of slag resulting from combustion of municipal sewage sludge in "Pomorzany" waste treatment plant in Szczecin and to determine the possibility of using it as: an alternative source of phosphorus for direct application to soil treatment, production of organic - mineral fertilizers and as construction aggregate for manufacturing concrete mortars .

\section{Sludge management in the "Pomorzany" waste treatment plant in Szczecin}

The "Pomorzany" Waste Treatment Plant in Szczecin ensures the required parameters of treated sewage. However, the greater the effectiveness of treatment, the more waste remains after the purification process.

Waste removed at the start of the mechanical treatment - the screenings - the residue of sifting via the gratings and sand - suspended mineral solids removed at the sand traps, are subjected only to rinsing to reduce the organic parts content, and their content of water is reduced - by compression in case of screenings or separation on a screw conveyor for sand. The main role of sludge processing is to minimize their amount and volume through draining part of the water and neutralization of the sludge - so that it does not pose a threat to the environment. The first phase of handling sludge is to drain part of the water in the process of compaction. Due to different properties of the initial and excessive sludge, compaction is carried out in different ways [13]. The initial sludge is periodically received from the sedimentary hoppers of primary settling tanks and then is gravitationally concentrated. The concentrated sludge from the bottom is periodically received and transported to the mixed sludge tank. The thickened excess sludge is also fed to this tank. The excess sludge is periodically received from the active sludge chambers. The biological structure of sludge means that most of the water contained in it is water bound in the cells. Before feeding the sludge into the compaction device, it is conditioned using polyelectrolytes. The general flow diagram of sludge management is shown in Figure 1.

The initial sludge is gravitationally pre-compacted up to about $5 \%$ of dry weight, the excessive sludge concentrated in mechanical compactors contains about $6 \%$ of dry 
weight. The initial and excessive sludge, after concentration, is discharged to the concentrated sludge tank and from there, by means of pumps, it is forced into two closed septic tanks. Inside them, mesophilic fermentation is performed at a temperature of approx. $37^{\circ} \mathrm{C}$. The biogas produced inside the chamber is stored in two double-shell tanks with a capacity of $1500 \mathrm{~m}^{3}$ each, and after desulfurization using the biosulfex method (the process results in elemental sulfur), is used as fuel in cogeneration units.

The Department of Water Supply and Sewage Ltd. in Szczecin has chosen a technology of thermal disposal of sewage sludge. This technology is based on dehydration of sludge by means of four conveyor presses, up to a dry weight content of about $20 \%$, drying in contact dryers up to $90-92 \%$ dry weight and burning in two boilers of two steam boilers with power of $2460 \mathrm{~kW}$.

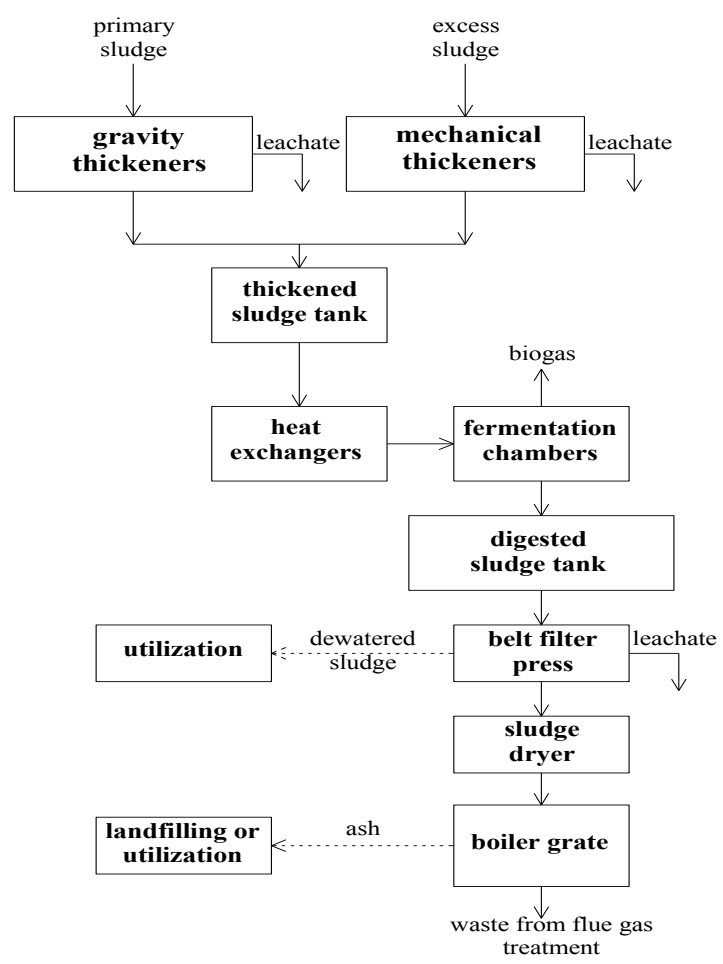

Fig 1. Block diagram of the sludge management technologies.

\section{Research methods}

The study used slag after combustion of municipal sewage sludge (waste code 1908 05) in the "Pomorzany" Waste Treatment Plant, code 190112.

The analytical physicochemical properties of the tested slag were performed using reference methods, in accordance with applicable standards and instructions pH - PN-EN 12176: 2004, dry weight - BS EN 12880: 2004, mineral and organic substances - PN-EN 12879:2004, phosphorus - PN-EN ISO 6878:2006, Ca, Co, Cu, Fe, K, Cd, Mg, Mn, Na, Ni, Pb, Zn - PN-EN 13657:2006. 


\section{Discussion of results}

In 2016, 16485.3 $\mathrm{Mg}$ of sewage sludge was transferred for incineration in the "Pomorzany" waste treatment plant, with dry weight content of $20 \%$, with a monthly average of $1498.7 \mathrm{Mg}$ (table 1).

Table 1. Mass of municipal sewage sludge [in $\mathrm{Mg}$ ] of average content $20 \%$ d.m. received in Pomorzany Sewage Treatment Plant in Szczecin in 2016

\begin{tabular}{|c|c|c|c|c|c|c|c|c|c|c|c|c|}
\hline 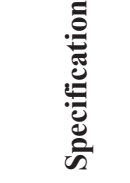 & 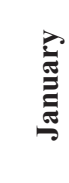 & 恶 & $\begin{array}{l}\bar{e} \\
\frac{\bar{U}}{\tilde{J}}\end{array}$ & $\overline{\frac{2}{2}}$ & $\sum^{\mathrm{J}}$ & $\stackrel{\mathscr{E}}{\Xi}$ & $\frac{\vec{D}}{\Xi}$ & $\begin{array}{l}\overrightarrow{0} \\
\overline{0} \\
\vec{z}\end{array}$ & हैं & $\frac{\dot{0}}{\frac{0}{0}}$ & 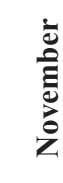 & 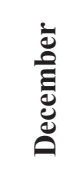 \\
\hline $\begin{array}{l}\text { Mass } \\
{[\mathrm{MG}]}\end{array}$ & $\begin{array}{c}744 . \\
1\end{array}$ & $\begin{array}{c}925 . \\
0\end{array}$ & $\begin{array}{c}962 . \\
7\end{array}$ & $\begin{array}{c}210 . \\
9\end{array}$ & $\begin{array}{c}232 . \\
8\end{array}$ & $\begin{array}{c}611 . \\
3\end{array}$ & $\begin{array}{c}431 . \\
9\end{array}$ & $\begin{array}{c}98 . \\
9\end{array}$ & $\begin{array}{c}339 . \\
2\end{array}$ & $\begin{array}{c}\text { n.d. } \\
*\end{array}$ & $\begin{array}{c}377 . \\
7\end{array}$ & $\begin{array}{c}751 . \\
0\end{array}$ \\
\hline Sum & \multicolumn{12}{|c|}{16485.3} \\
\hline Average & \multicolumn{12}{|c|}{1498.7} \\
\hline $\begin{array}{c}\text { Maksimu } \\
\text { m }\end{array}$ & \multicolumn{12}{|c|}{2032.8} \\
\hline $\begin{array}{c}\text { Minimu } \\
\mathrm{m}\end{array}$ & \multicolumn{12}{|c|}{377.7} \\
\hline
\end{tabular}

Slag is formed as a result of incineration of dehydrated sludge in a mechanical grid boiler.

This sludge was sifted on a vibrating shaker and fractions were separated. Table 2 lists the particle size of the slag fractions. with content of grains with individual diameters. Studies have shown that $29.2 \%$ was formed by the fraction of $<500 \mu \mathrm{m}$. and $0.3 \%$ was formed by fractions of 5 and $4 \mathrm{~mm}$.

Figures 2 and 3 show the appearance and structure of the slag samples in crude form.

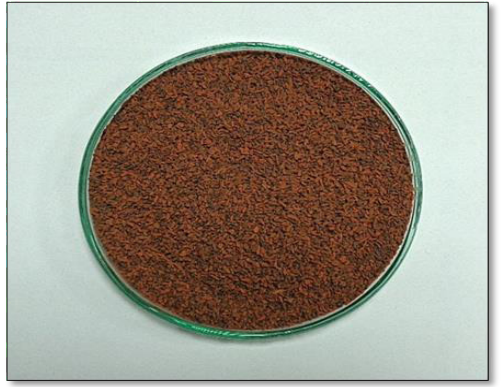

Fig. 2. Slag from the combustion of sewage sludge. fraction $800 \mu \mathrm{m}$.

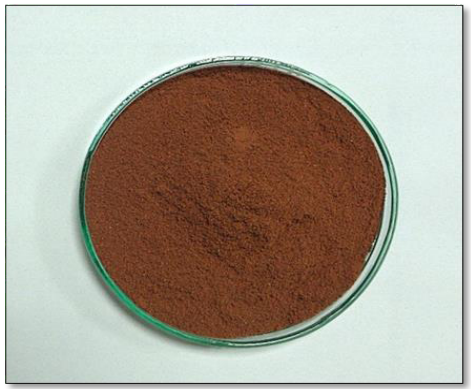

Fig. 3. Slag from the combustion of municipal sewage sludge. fraction $<500 \mu \mathrm{m}$.

Figures 2 and 3 show the appearance and structure of the slag samples in crude form.

The chemical and physical properties of the test material are presented in Table 3 and Table 4. The total content of individual heavy metals in the material collected in 2015 forms a series of decreasing values of $\mathrm{Zn}>\mathrm{Cu}>\mathrm{Mn}>\mathrm{Fe}>\mathrm{Ni}>\mathrm{Pb}>\mathrm{Co}>\mathrm{Cd}$. Analyzing the amount of elements identified in previous years. we can see a large increase in the concentration of zinc and copper. respectively amounting to $1925.07 \mathrm{mg}$ $\mathrm{Zn} \mathrm{kg}^{-1}$.dry weight and $1591.56 \mathrm{mg} \mathrm{Cu} \mathrm{kg}^{-1}$.dry weight. The content of lead. cadmium and 
manganese has decreased. In 2015. the ashes from incineration of sewage sludge contained five times more potassium than in 2011-2013. Analyzing the standard deviations. the smallest variation of the chemical composition of ash may be observed in case of the amounts of soluble forms of phosphorus and total content of calcium. magnesium and cadmium.

Table 2. Granulation of slag from the combustion of municipal sewage sludge.

\begin{tabular}{|c|c|c|}
\hline $\begin{array}{c}\text { The diameter of the mesh } \\
\text { sieve }\end{array}$ & $\begin{array}{c}\text { Mass fraction of residua the } \\
\text { sieve } \mathbf{~ [ g ]}\end{array}$ & $\begin{array}{c}\text { Percentage } \\
\text { a fraction }\end{array}$ \\
\hline$<6.3 \mathrm{~mm}$ & 533.40 & 7.9 \\
\hline $5.0 \mathrm{~mm}$ & 17.75 & 0.3 \\
\hline $4.0 \mathrm{~mm}$ & 18.03 & 0.3 \\
\hline $3.15 \mathrm{~mm}$ & 66.77 & 1.0 \\
\hline $2.5 \mathrm{~mm}$ & 188.14 & 2.8 \\
\hline $2.0 \mathrm{~mm}$ & 280.16 & 4.1 \\
\hline $1.25 \mathrm{~mm}$ & 1210.56 & 17.8 \\
\hline $800 \mu \mathrm{m}$ & 1362.58 & 20.1 \\
\hline $630 \mu \mathrm{m}$ & 702.47 & 10.4 \\
\hline $500 \mu \mathrm{m}$ & 412.87 & 6.1 \\
\hline$<500 \mu \mathrm{m}$ & 1977.19 & 29.2 \\
\hline Summ & 6769.92 & 100.0 \\
\hline
\end{tabular}

The chemical and physical properties of the test material are presented in Table 3 and Table 4. The total content of individual heavy metals in the material collected in 2015 forms a series of decreasing values of $\mathrm{Zn}>\mathrm{Cu}>\mathrm{Mn}>\mathrm{Fe}>\mathrm{Ni}>\mathrm{Pb}>\mathrm{Co}>\mathrm{Cd}$. Analyzing the amount of elements identified in previous years. we can see a large increase in the concentration of zinc and copper. respectively amounting to $1925.07 \mathrm{mg}$ $\mathrm{Zn} \mathrm{kg}^{-1}$.dry weight and $1591.56 \mathrm{mg} \mathrm{Cu} \mathrm{kg}{ }^{-1} \cdot$ dry weight. The content of lead. cadmium and manganese has decreased. In 2015. the ashes from incineration of sewage sludge contained five times more potassium than in 2011-2013. Analyzing the standard deviations. the smallest variation of the chemical composition of ash may be observed in case of the amounts of soluble forms of phosphorus and total content of calcium. magnesium and cadmium.

Slag samples obtained for research was characterized with alkaline reaction. It had dry weight content of $95.50 \%$ and $1.27 \%$ of organic matter (Table 4 ).

Table 4. The physical characteristics of slag.

\begin{tabular}{|c|c|c|c|c|c|c|}
\hline Specification & $\mathrm{pH}$ & $\begin{array}{c}\text { Conductivity } \\
{[\mathrm{mS} / \mathrm{cm}]}\end{array}$ & $\begin{array}{c}\text { Humidity } \\
{[\% \text { d.m }]}\end{array}$ & $\begin{array}{c}\text { Dry mass } \\
{[\% \mathrm{~d} . \mathrm{m}]}\end{array}$ & $\begin{array}{c}\text { Mineral } \\
\text { substance } \\
{[\% \mathrm{~d} . \mathrm{m}]}\end{array}$ & $\begin{array}{c}\text { Organic } \\
\text { matter }[\% \\
\text { d.m }]\end{array}$ \\
\hline Slag & 8.03 & 2.835 & 6.50 & 93.50 & 98.73 & 1.27 \\
\hline
\end{tabular}

While searching for ways of utilizing sewage sludge in the form of slag. an attempt was made to evaluate slag's suitability for being used as fine-grained aggregate for cementitious mortars. Hence. it was necessary to determine density of the waste and. for this purpose. pycnometer method was used in accordance with norm PN-88/B-04481. Due to conducted research. density result of $2.86 \mathrm{~g} / \mathrm{cm}^{3}$ was obtained. This is a value higher compared to typical natural aggregate - quartz sand $\left(2.65 \mathrm{~g} / \mathrm{cm}^{3}\right)$. Furthermore, a microscope evaluation was also conducted with the use of both stereo (Figure 4a) and electron (Figure 4b) microscopes.

Images on Figure 4 clearly indicate the porous structure of slag. From one side, this a positive trait due to the fact that it results in low volumetric density and provides an 
advantage of convenient thermal insulation. On the other side however. it results in lower level of mechanical durability and increased water absorption.

Table 3. The chemical composition of ash from the incineration of municipal sewage sludge.

\begin{tabular}{|c|c|c|c|c|c|c|c|c|c|c|c|c|c|c|}
\hline \multirow[b]{3}{*}{$\begin{array}{c}\text { Year } \\
\text { of } \\
\text { sampl } \\
\text { ing }\end{array}$} & \multirow{2}{*}{\multicolumn{3}{|c|}{$\begin{array}{c}\text { The content of } \\
\text { soluble forms } \\
\mathrm{P}_{2} \mathrm{O}_{5}[\%]\end{array}$}} & \multirow{2}{*}{\multicolumn{3}{|c|}{$\begin{array}{l}\text { The total } \\
\text { content [\%] }\end{array}$}} & \multicolumn{8}{|c|}{ The total content } \\
\hline & & & & & & & \multicolumn{8}{|c|}{$\left[\mathrm{mg} \cdot \mathrm{kg}^{-1}\right.$ d.m.] } \\
\hline & $\begin{array}{c}\text { stron } \\
\mathrm{g} \\
\text { mine } \\
\text { ral } \\
\text { acid } \\
\mathrm{s}\end{array}$ & $\begin{array}{c}2 \% \\
\text { citri } \\
\mathrm{c} \\
\text { acid }\end{array}$ & $\begin{array}{l}\text { in } \\
\text { the } \\
\text { wat } \\
\text { er }\end{array}$ & K & $\mathrm{Ca}$ & $\mathrm{Mg}$ & $\mathrm{Cd}$ & $\mathrm{Cu}$ & $\mathrm{Mn}$ & $\mathrm{Ni}$ & $\mathrm{Pb}$ & $\mathrm{Zn}$ & Co & $\mathrm{Fe}$ \\
\hline 2011 & $\begin{array}{c}22.0 \\
50\end{array}$ & $\begin{array}{c}12.0 \\
80\end{array}$ & $\begin{array}{l}7.6 \\
40\end{array}$ & $\begin{array}{c}4.26 \\
0\end{array}$ & $\begin{array}{l}6.2 \\
20\end{array}$ & $\begin{array}{l}3.8 \\
70\end{array}$ & $\begin{array}{l}4.1 \\
60\end{array}$ & $\begin{array}{c}476.2 \\
00\end{array}$ & $\begin{array}{l}411 . \\
400\end{array}$ & $\begin{array}{c}74.7 \\
00\end{array}$ & $\begin{array}{c}93.0 \\
00\end{array}$ & $\begin{array}{c}745.1 \\
00\end{array}$ & - & - \\
\hline 2013 & $\begin{array}{c}16.3 \\
00\end{array}$ & $\begin{array}{c}9.98 \\
0\end{array}$ & $\begin{array}{l}5.1 \\
40\end{array}$ & $\begin{array}{c}4.96 \\
0\end{array}$ & $\begin{array}{l}6.9 \\
70\end{array}$ & $\begin{array}{l}4.6 \\
70\end{array}$ & $\begin{array}{l}2.3 \\
90\end{array}$ & $\begin{array}{c}310.3 \\
00\end{array}$ & $\begin{array}{l}476 . \\
900\end{array}$ & $\begin{array}{c}18.0 \\
00\end{array}$ & $\begin{array}{c}84.3 \\
00\end{array}$ & $\begin{array}{c}820.1 \\
90\end{array}$ & - & - \\
\hline 2015 & $\begin{array}{c}23.1 \\
50\end{array}$ & - & & $\begin{array}{c}26.4 \\
17\end{array}$ & & $\begin{array}{l}4.7 \\
95\end{array}$ & $\begin{array}{l}0.3 \\
00\end{array}$ & $\begin{array}{c}1591 . \\
560\end{array}$ & $\begin{array}{l}367 . \\
960\end{array}$ & $\begin{array}{c}66.7 \\
60\end{array}$ & $\begin{array}{c}17.9 \\
60\end{array}$ & $\begin{array}{c}4209 . \\
920\end{array}$ & $\begin{array}{c}13.9 \\
70\end{array}$ & $\begin{array}{l}179 . \\
880\end{array}$ \\
\hline $\begin{array}{c}\text { Średni } \\
\text { a }\end{array}$ & $\begin{array}{c}20.5 \\
00\end{array}$ & $\begin{array}{c}11.0 \\
30\end{array}$ & $\begin{array}{l}6.3 \\
90\end{array}$ & $\begin{array}{c}11.8 \\
79\end{array}$ & $\begin{array}{l}6.5 \\
95\end{array}$ & $\begin{array}{l}4.4 \\
45\end{array}$ & $\begin{array}{l}2.2 \\
83\end{array}$ & $\begin{array}{c}792.6 \\
87\end{array}$ & $\begin{array}{l}418 . \\
753\end{array}$ & $\begin{array}{c}53.1 \\
53\end{array}$ & $\begin{array}{c}65.0 \\
87\end{array}$ & $\begin{array}{c}1925 . \\
070\end{array}$ & - & - \\
\hline $\begin{array}{l}\text { Maksi } \\
\text { mun }\end{array}$ & $\begin{array}{c}23.1 \\
50\end{array}$ & $\begin{array}{c}2.08 \\
0\end{array}$ & $\begin{array}{l}7.6 \\
40\end{array}$ & $\begin{array}{c}26.4 \\
17\end{array}$ & $\begin{array}{l}6.9 \\
70\end{array}$ & $\begin{array}{l}4.7 \\
95\end{array}$ & $\begin{array}{l}4.1 \\
60\end{array}$ & $\begin{array}{c}1591 . \\
560\end{array}$ & $\begin{array}{l}476 . \\
900\end{array}$ & $\begin{array}{c}74.7 \\
00\end{array}$ & $\begin{array}{c}93.0 \\
00\end{array}$ & $\begin{array}{c}4209 . \\
920\end{array}$ & - & - \\
\hline $\begin{array}{l}\text { Minim } \\
\text { un }\end{array}$ & $\begin{array}{c}16.3 \\
00\end{array}$ & $\begin{array}{c}9.98 \\
0\end{array}$ & $\begin{array}{l}5.1 \\
40\end{array}$ & $\begin{array}{c}4.26 \\
0\end{array}$ & $\begin{array}{l}6.2 \\
20\end{array}$ & $\begin{array}{l}3.8 \\
70\end{array}$ & $\begin{array}{l}0.3 \\
00 \\
\end{array}$ & $\begin{array}{c}310.3 \\
00\end{array}$ & $\begin{array}{l}367 . \\
960\end{array}$ & $\begin{array}{c}18.0 \\
00\end{array}$ & $\begin{array}{c}17.9 \\
60\end{array}$ & $\begin{array}{c}745.1 \\
00\end{array}$ & - & - \\
\hline $\begin{array}{l}\text { Standa } \\
\text { rd } \\
\text { deviati } \\
\text { on }\end{array}$ & $\begin{array}{c}3.67 \\
9\end{array}$ & $\begin{array}{c}1.48 \\
5\end{array}$ & $\begin{array}{l}1.7 \\
68\end{array}$ & $\begin{array}{c}12.5 \\
95\end{array}$ & $\begin{array}{l}0.5 \\
30\end{array}$ & $\begin{array}{l}0.5 \\
02\end{array}$ & $\begin{array}{l}1.9 \\
32\end{array}$ & $\begin{array}{c}696.8 \\
00\end{array}$ & $\begin{array}{c}54.8 \\
41\end{array}$ & $\begin{array}{c}30.7 \\
01\end{array}$ & $\begin{array}{c}41.0 \\
44\end{array}$ & $\begin{array}{c}1979 . \\
094\end{array}$ & - & - \\
\hline
\end{tabular}
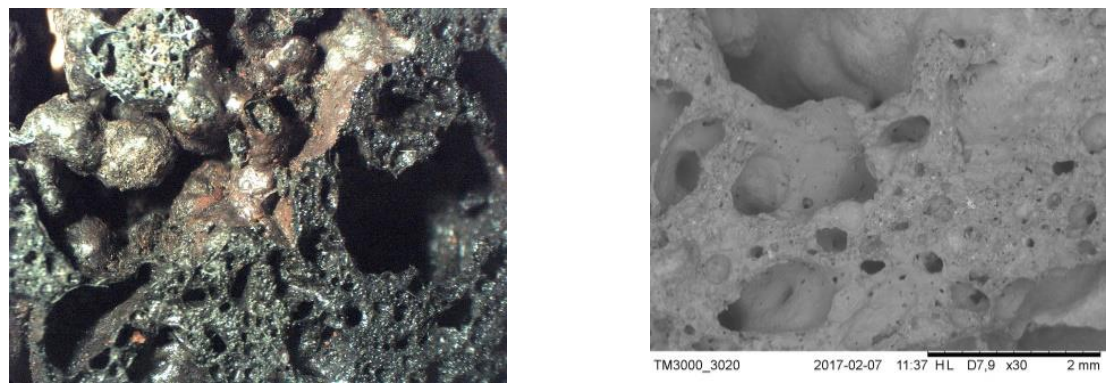

Fig. 4. Image of microstructure of slag enlarged: a) $10 \mathrm{x}$, b) $30 \mathrm{x}$.

In order to utilize this waste as a fine-grained aggregate for construction mortars. it is necessary to pass it through a set of sieves corresponding with mesh size for screening natural sand - Figure 5. which will allow slag to be combined into the mortar mixture.
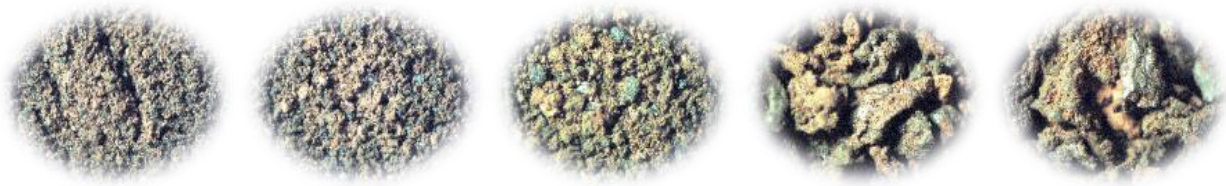

Fig. 5. Fine-grained recycling aggregate with fraction division. From left $0 / 0.063 ; 0.125 / 0.25$;

$0.25 / 0.5 ; 0.5 / 1 ; 1 / 2$. 
Nonetheless, it is worth remembering that slag's porous structure would require a special procedure of regulating the amount of water dosed into the mortar mixture. This will comprise the sum of batched water and water added. which results from the aggregate's absorption while the components are being mixed. This has both advantages and disadvantages. What is a positive aspect is the fact that water absorbed by the slag's grains during maturing period encourages self-care in the grain-cementitious matrix contact area. As a consequence. it enhances the adhesion of both elements. Furthermore. one can also expect increase of tensile strength of the composite due to the added waste [14]. The disadvantage is the fact that an excessive amount of water. unused during the hydration reaction process. leaves microporous material while evaporating during the maturing period. which undermines the structure of the obtained composite. Nonetheless. bearing in mind different needs regarding the properties of cementitious mortars. the usage of slag allows for obtaining lower volumetric density compared to traditional mortars. more convenient thermal insulation properties as well as an interesting coloring. Furthermore. this also complies with expectations set out in Regulation no 305/2011 of European Parliament and Council (EU) of 9th March 2011. regarding the introduction of construction products manufactured with the use of secondary recycled and raw materials to the EU market.

Scanning electron microscope Hitachi TM 3000 equipped with EDS unit was used in order to determine the elemental composition of the analyzed slag - Figure 6. This allowed to observe the elemental concentration spectrum (Figure 7).

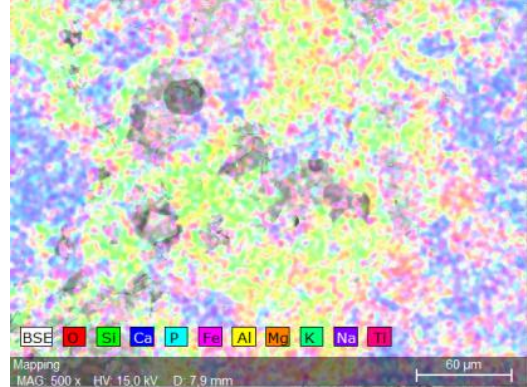

a)

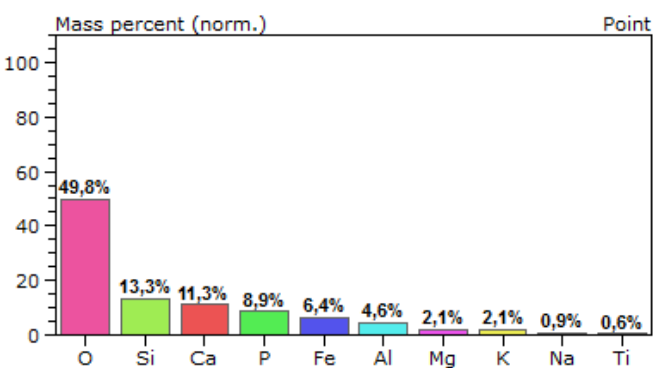

b)

Fig. 6. a) Map of identified elements on the slag's observed surface; (b) along with their percentage share.

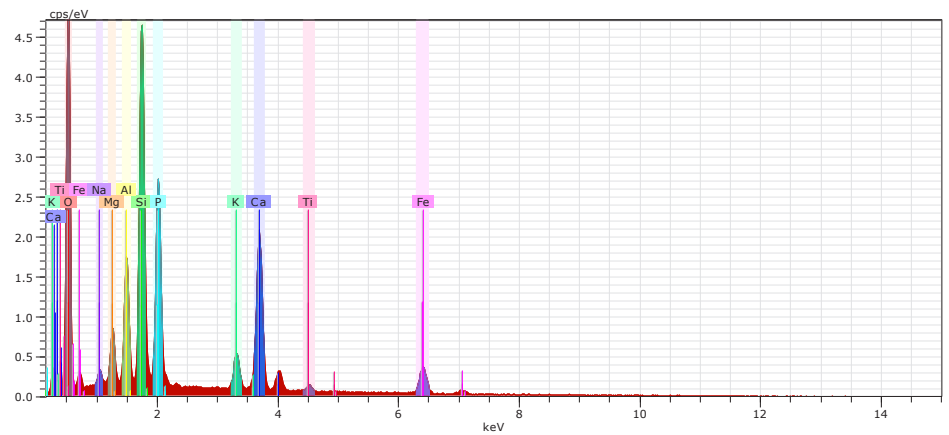

Fig. 7. Energy spectrum of elements identified on the slag's observed surface.

As indicated by the presented summarizing of elements - Figure 6b), the analyzed slag either lacks heavy metals or their concentration is so low that it cannot be detected by EDS. This provides the guarantee of safe use of this waste in construction mortars as well 
as floor and plaster coatings. Initial research in this matter has already been launched by the authors.

\section{Conclusions}

1. The slags resulting from the process of thermal treatment of sewage sludge in the "Pomorzany" waste treatment plant have a neutral reaction and contain $98.73 \%$ mineral matter.

2. The chemical composition of slag does not exceed the permissible norms contained in the Regulation of the Minister of Agriculture and Rural Development of 18 June 2008 on the implementation of certain provisions of the Act on fertilizers and fertilization. Journal of Laws 2008 No. 119. item. 765.

3. The content of phosphorus in the slag ranged from 16.300 to $23.150 \% \mathrm{P}_{2} \mathrm{O}_{5}$. This waste may be used as: alternative source of phosphorus for direct application to soil fertilization and for organic - mineral fertilizer production.

4. The obtaining of slag granulation corresponding to the grain size of the sand. without the necessity of further treatment. and the marked density and microscopic analysis. provide the basis for further research into the use of this recycled material in construction mortars. As already mentioned. such research is already under way. and the test results obtained so far for essential technical characteristics. including mechanical strength. confirm the usefulness of slag in cement composites technology.

\section{References}

1. I. Białobrzewski, M. Mikš-Krajnik, J. Dach, M. Markowski, W. Czekała, K. Głuchowska, Waste Management, 43 (2015)

2. J.B. Bień, Sewage sludge. Theory and practice (Częstochowa, 2002) (in Polish)

3. E. Iacovidou, D.G. Ohandja, N. Voulvoulis, J. Env. Management, 112 (2012)

4. J. Mata-Alvarez, J. Dosta, M.S. Romero-Güiza, X. Fonoll, M. Peces, S. Astals, Renewable and Sustainable Energy Reviews, 36 (2014)

5. J.B. Bień, Environmental Protection Engineering 15, 4 (2012) (in Polish)

6. P. Cornel, A. Meda, S. Bieker, Wastewater as a source of energy. nutrients and service water. Treatise in Water Science (Elsevier Verlag, 2011)

7. Environmental Protection 2014. Ochrona Środowiska 2014. Statistical yearbooks GUS (Warszawa, 2015) (in Polish)

8. J.B. Bień, E. Neczaj, M. Worwąg, A. Grosser, D. Nowak, M. Milczarek, M. Janik, Inżynieria i Ochrona Środowiska 14, 4 (2011)

9. J.B. Bień, B. Bień, Inżynieria Ekologiczna, 45 DOI: $10.12912 / 23920629 / 60592$

10. B. Chefetz, Y. Hadar, Y. Chen, Acta Hydrochimca et hydrobiologica 26, 3 (1998)

11. J. Perez, J. Munoz-Dorado, T. de la Rubia, International Microbiology, 5 (2002)

12. S.J. Balogh, L. Liang, Water Air Soil Pollution, 80 (1995)

13. Operating data wastewater treatment plant "Pomorzany". Received from Zakład Wodociągów i Kanalizacji Sp. z o.o. in Szczecin (2014)

14. A.M Neville, Properties of Concrete, (Polish Cement Association, 758-762, Kraków 2012) 